\title{
Public Consultation on Proposed Revisions to Norway's Gene Technology Act: An Analysis of the Consultation Framing, Stakeholder Concerns, and the Integration of Non-Safety Considerations
}

\author{
Sigfrid Kjeldaas ${ }^{1,2, *}$, Trine Antonsen ${ }^{1,3}$, Sarah Hartley ${ }^{4} \mathbb{D}$ and Anne Ingeborg Myhr ${ }^{1}$ \\ 1 GenØk Centre for Biosafety, NO-9294 Tromsø, Norway; trine.antonsen@genok.no (T.A.); \\ anne.myhr@genok.no (A.I.M.) \\ 2 Department of Culture and Literature, UiT The Arctic University of Norway, NO-9037 Tromsø, Norway \\ 3 Department of Philosophy, UiT The Arctic University of Norway, NO-9037 Tromsø, Norway \\ 4 Department of Science, Innovation, Technology and Entrepreneurship, University of Exeter, \\ Exeter EX4 4PU, UK; sarah.hartley@exeter.ac.uk \\ * Correspondence: sigfrid.kjeldaas@genok.no; Tel.: +47-776-46763
}

check for updates

Citation: Kjeldaas, S.; Antonsen, T.; Hartley, S.; Myhr, A.I. Public Consultation on Proposed Revisions to Norway's Gene Technology Act: An Analysis of the Consultation Framing, Stakeholder Concerns, and the Integration of Non-Safety Considerations. Sustainability 2021, 13, 7643. https://doi.org/10.3390/ su13147643

Academic Editors: Hamid El Bilali, Carola Strassner and Tarek Ben Hassen

Received: 2 June 2021

Accepted: 5 July 2021

Published: 8 July 2021

Publisher's Note: MDPI stays neutral with regard to jurisdictional claims in published maps and institutional affiliations.

Copyright: (c) 2021 by the authors. Licensee MDPI, Basel, Switzerland. This article is an open access article distributed under the terms and conditions of the Creative Commons Attribution (CC BY) license (https:// creativecommons.org/licenses/by/ $4.0 /)$.

\begin{abstract}
In Norway, genetically modified organisms (GMOs) are regulated through the Gene Technology Act of 1993, which has received international attention for its inclusion of non-safety considerations. In 2017, the Norwegian Biotechnology Advisory Board triggered a process to revise the Act that included a public consultation and resulted in the "Proposal for relaxation." Using poststructuralist discourse analysis, we critically analyze the premises and processes through which the proposal for relaxation was developed-including the public consultation-to understand the range of stakeholder concerns and how these concerns shaped the final proposal. We find that the proposal does not include all concerns equally. The Norwegian Biotechnology Advisory Board's privileging of technological matters and its preference for tier-based regulation skewed the proposal in a way that reduced broader societal concerns to technological definitions and marginalized discussion of the social, cultural, and ethical issues raised by new gene technologies. To prevent such narrowing of stakeholder concerns in the future, we propose Latour's model for political economy as a tool to gauge the openness of consultations for biotechnology regulation.
\end{abstract}

Keywords: GMO regulation; non-safety considerations; consultation; perplexity; sustainability; ethics; GMOs; genome editing

\section{Introduction}

In Norway, genetically modified organisms (GMOs) are regulated through the Gene Technology Act of 1993 (GTA). The GTA is unusual in that it includes non-safety considerations, demanding that GMO production and use take place in "an ethically justifiable and socially acceptable manner" without harm to health and the environment [1] (Article 1). It demonstrates similarities with Article 26 of the Cartagena Protocol on Biosafety and the EU's Directive on GMOs (EU 2015/412), which allows member states to restrict GMOs "based on grounds related to socio-economic impacts" cf. [2,3]. Although Norway is not a part of the European Union (EU), EU Directive 2001/18/EC [4] is applicable to Norway due to Norway's obligations through the European Economic Area (EEA) agreement. This implies that an approval of a GMO in the EU automatically leads to an approval in Norway, unless it is prohibited. As of June 2021, Norwegian authorities have approved five GM carnations with changed color, whereas 13 GMO applications approved in the EU have been forbidden in Norway (10 GM plants, two vaccines, and one test kit that contains GM microorganisms) [5]. 
To aid implementation of the GTA, the Norwegian Biotechnology Advisory Board (NBAB) has established detailed guidance documents for the assessment of two of the non-safety considerations [6-9]. The societal utility criterion in the GTA is only relevant for impacts of the product within Norway, whereas the sustainability criterion may take into consideration factors that evolve over the longer term or affect global developments. In 2017 the Norwegian government prohibited a GM maize on ethical grounds. This prohibition initiated the development of a guide for ethical assessments [10], which the Ministry of Climate and Environment is currently evaluating.

Despite such work to concretize non-safety assessments, there still exists a widespread conception that non-safety assessments place additional regulatory burdens on GMO regulation and present a barrier to the technology's development [11]. There is further disagreement on what constitutes non-safety considerations and the scope of such assessments $[3,12,13]$. In Norway, experience with current regulation has caused concern among biotech and breeding companies that the GTA's non-safety assessments could be used to ban any GM product from the Norwegian market. Recent surveys reveal a slight majority of the Norwegian public to believe GMOs will have negative effects on natural ecosystems and human and animal health, and to place more emphasis on non-safety assessments [14-16]. (These findings are presented in survey reports that are issued by scientific environments, but that have not been submitted to scientific peer review processes. Accordingly, charges of bias have been made against them [17-20] and their results must be used with precaution.) In line with the findings of Menozzi et al. [21], broader public engagement appears to evoke a broader set of concerns, and effective forms of public engagement may be used to identify research needs on the socio-economic effects of the possible development and use of new GMOs.

NBAB is an independent body of government-appointed experts with responsibility to assess GMO applications based on their impact on sustainability, societal utility, or ethics; advise the Ministry of Climate and Environment on whether to approve or dismiss such applications; and facilitate knowledge dissemination and public debate on topics it deems important [22,23]. In 2017, NBAB published a report entitled "The Gene Technology Act-Invitation to public debate" [22,24]. The report invited public comment on its proposal to relax the GTA in order to reduce the regulatory burden on applicants and accommodate advances in genome editing. NBAB argued that the GTA had not kept pace with the emerging scientific developments in gene technology. For example, the relative simplicity and low cost of using emerging gene technologies meant an increase in applications for GMO-product approvals was likely and the GTA needed to provide a stable, easily operationalized, and predictable framework for the corresponding assessments. The inclusion of non-safety considerations posed a potential barrier to this goal.

The public consultation took place between December 2017 and May 2018 and garnered 46 Norwegian submissions. In light of these public submissions, NBAB published the revised "Proposal for relaxation of Norwegian regulations for deliberate release of genetically modified organisms (GMO), with applicability also for EU legislation" in December 2018 [25]. The proposal outlined a differentiated regulatory system based on biological categorizations and maintained that non-safety assessments should remain. In response, in 2020, the Ministry of Climate and Environment appointed a committee tasked to develop a white paper on GMO regulation before the end of 2022.

NBAB's proposed "Norwegian model" is internationally recognized $[26,27]$ and considered a possible model for the EU, as it strikes a balance between harnessing the potential of gene technologies and accommodating public and stakeholder concerns [11]. Given the prominence of Norway's approach to the treatment of non-safety assessments in biotechnology regulation, there is a need to investigate this potential regulatory shift. Importantly, there is a need to understand how non-safety considerations fare under pressure to relax regulations and how public and stakeholder input shaped the relaxation proposal. We address this need through a poststructuralist (Foucauldian) discourse analysis to investigate (1) NBAB's framing of the problem and the consultation, (2) public and stakeholder 
concerns raised through the consultation, and (3) NBAB's integration of these concerns in its final proposal.

We outline the ways in which NBAB's problem framing shaped the public consultation and show how some stakeholders shaped the final proposal more than others. Our humanities-based study seeks to contribute to cross-disciplinary dialogue by revealing the concepts and narratives upon which current problem definitions depend, and how they change according to the different actors' vocational, political, and ideological positions within the field of debate. Furthermore, we apply Latour's model for political ecology [28] as a measure of how well NBAB succeeds in engaging the public in a broad and inclusive consultation on the development and use of gene technologies. This gives us an indication of the way these technologies support or challenge current non-safety assessments. We argue that if gene technologies are to address sustainability challenges, as their proponents claim, broader and more inclusive discussions are needed that include biological and ecological parts of (nature-culture) collectives as essential to both safety and non-safety considerations.

\section{Latour's Model for Political Ecology}

The scientific facts of gene technology have shaped public policy in ways that favor permissive regulatory regimes and the prerogative of geneticists to "push research to its limits" until it challenges technically defined limits of risk to human health or the environment [29] (p. 26). Historically, this framing of scientific risk has subordinated the social and ethical aspects of gene technology to scientific issues, leaving them "a marginal role in the development of governance structures" [30] (p. 781); cf. [31-33]. The emergence of a high-profile ethical agenda for GMOs in Europe has been unable to improve this situation because it relies on deontological or utilitarian approaches that presuppose that harms and benefits can be readily identified, and that conceives of ethical judgements in terms of individual convictions based on emotions [33]. The public is left with the choice "either to recognize and accept what the scientists [say] about risks, or to be defined as irrational and emotive" [33] (p. 455). According to Wynne [33], this causes a situation in which public concerns involving a combination of intellectual and ethical judgements on scientific knowledge and forms of ownership, including the quality of scientific institutions and their willingness to discuss the limitations of their own knowledge culture, are severely underestimated. In this manner, a clear separation between "scientific facts" and "ethical concerns" - often supported by derogatory representations of the intellectual capacities of the public-serves to protect scientific-based policy cultures from self-reflexivity [33]. Non-governmental organizations (NGOs) and other actors concerned with the broader socio-cultural and ethical consequences of gene technology suspect their concerns are neglected [30], which hampers deliberation on the regulation and use of the technology.

Latour's model of political ecology, outlined in Politics of Nature [28], is designed specifically to deal with tensions between facts and values and/or experts and lay publics. Latour argues "it is impossible to begin to ask the moral question after the states of the world have been defined," and offers a model in which "the question of what ought to be is not a moment in the process; rather, it is coextensive with the entire process" [28] (p. 125). Instead of leaving it up to the scientist to decide what constitutes the common world and up to politicians and philosophers to determine what a good world looks like, Latour's political-ecological collective outlines a model in which multiple actors with specific and valuable expertise partake in the construction of a good common world [28] (p. 93).

Central to Latour's model for political ecology is a re-conceptualization of traditional fact-value distinctions and of what it means to properly take into account all viewpoints and arguments in deliberations on what constitutes a good common world. Latour specifies that the power of taking into account consists of two processes: consultation and perplexity. Perplexity has to do with the processes through which natural facts are constructed. It denotes a state of bewilderment and momentary incomprehension experienced as scientists (and other producers of knowledge) encounter new entities that make an impact on 
the world yet exist beyond what scientific instruments can measure; what theories and paradigms can make sense of and predict. These are "entities or phenomena presenting themselves initially in the first form, in the laboratory, on the research front, in the garb of beings of uncertain status that demand to be taken into account" [28] (p. 103). Latour names these entities propositions because of the way they propose their candidacy for existence in a common world [28] (p. 104). Propositions' key feature is the way they momentarily challenge established (and materially supported) knowledge production systems and leave those who are discussing them "perplexed" [28] (p. 104).

The function of consultation is to determine "what trials are appropriate to pass judgment on the existence, the importance, and the intention of a proposition" [28] (p. 239). Importantly, the process of consultation applies to non-humans as well as humans, and involves carefully putting together the best possible jury capable of judging the effect of each proposition on the already existing collective of humans and nonhumans. Drawing on politicians' expertise in making all voices heard, consultation, in Latour's reformulation, "does not have the ordinary meaning of [debating] an answer to an already-formulated question," but implies active "participation in the reformulation of the problem through a search for reliable witnesses" [28] (p. 239).

Latour's way of combining perplexity and consultation in the proper processes of taking something into account (what we may call deliberation) does two important things. First, it acknowledges the processes of construction through which natural "facts" become established and the initial states of indeterminacy and ignorance these processes often originate in. Second, it associates the processes of knowledge construction with the processes of consultation through which appropriate trials and reliable witnesses are sought. Latour's reconceptualization of the political-ecological collective in this way opens up for different and more participatory processes of knowledge construction in which a range of actors-providing a range of different forms of knowledge-are involved. In the case of GMOs, not only molecular scientists and producers of gene technology, but all kinds of biologists, ecologists, farmers, breeders and other producers of the technology, consumers, NGOs, and concerned citizens contribute to the construction of knowledge of what new GMOs are and may become. Democratic inclusion becomes a matter not only of the ability to participate in political processes (making all voices heard), but also a matter of allowing different voices to participate in the official production of what ends up as scientific-cultural matters of fact [28] (pp. 114, 128, 244). Latour's model resembles other models for democratic and open forms of public consultation (or engagement) seeking to establish better ways of co-producing knowledge [34,35], but goes beyond these by including propositions and those who articulate their candidacy into the conceptualization of consultation [28] (pp. 86, 237).

In this way, Latour's model highlights how the establishment of matters of fact are intricately associated with questions of who is accepted as a witness and allowed to engage in framing the discussion questions in debates on how to construct a good common world. Openness to perplexity becomes a question of value. Only by allowing this openness to remain - to take as much time and include as many propositions and voices as possiblecan the production of knowledge transcend the enclosed spaces of science and -in the case of gene technology-allow other questions to be formulated than whether or not the GMO produced is "safe enough" for application from the perspective of molecular biology.

Processes of taking into account are, moreover, acknowledged as fundamental to what we traditionally conceive of as discussions of value: the hierarchization of different and possibly conflicting ethical standards/principles that determines the place of new propositions within already established value systems [28] (p. 109). Thus, Latour's model shows great promise in clarifying that the framing of questions treated in considerations of new natural-technological propositions like GMOs and emerging genome edited organisms already involves the establishment of values-also when the framing appears to be purely scientific. Moreover, it highlights that neglecting perplexity is a way to partake in this 
value-laden framing, even in cases when this neglect consists primarily of not making full use of the potential and diversity of the sciences.

Latour's call for a broader integration of ethical and social concerns emerges at the core of the recent European Group on Ethics in Science and New Technologies' Opinion on the "Ethics of Genome Editing" [36], which specifically deals with the complex issue of how to evaluate the role and regulate the use of genome editing in a good, common world. By overtly questioning the "safe enough" narrative of molecular biology, in which ethics tends to become a secondary, justifying "add-on" to otherwise scientific assessments of gene technology and its products, the opinion challenges "the tendency of scientific and technological developments to mould governance and ethics" [36] (p. 21). Highlighting such real and experienced effects of the "safe enough" framing, it signals the relevance and possible impact of Latour's model of political ecology at this particular point in time. Here, both Norway and the EU are revisiting their GMO regulations in light of recent scientific developments and increasing pressures to coordinate national and regional regulations to allow global trade in GMO products [25,37]. In this context, the inclusiveness and form of consultation is key, and contended issues are how current or future GMO regulations may support long-term political goals and strategies for more sustainable food systems - as manifested globally in the UN Sustainable Development Goals and FAO's Sustainability Assessment of Food and Agriculture Systems [38,39], in the European Green Deal [40] and the EU Commission's Farm to Fork Strategy [41]. In these policy documents, socio-economic (and a limited range of ethical) concerns inform the understanding of sustainability, and hence the possible contribution of new gene technologies to sustainable development.

\section{Materials and Methods}

We designed a three-step method of poststructuralist discourse analysis to analyze (1) how NBAB's invitation framed the public debate, (2) concerns raised by stakeholders and public in the debate, and (3) how these concerns were represented in the final document. Our analysis focused on three publicly available documents: (D1) NBAB's 2017 "The Gene Technology Act-Invitation to public debate" [22,24], (D2) the written responses from 46 Norwegian respondents [42], and (D3) NBAB's 2018 "Proposal for relaxation of Norwegian regulations for deliberate release of genetically modified organisms (GMO)" [25] (see Table A1 in the Appendix A). D1 and D3 are published in both Norwegian and English. D2 is available in Norwegian only, and in order to perform a nuanced investigation of respondents' application and possible reworking of concepts and categories presented in D1, we analyzed the original Norwegian documents. For the reader's convenience, references to D1 [22,24] and D3 [25,43] refer to the English versions [22,25]. We excluded the report(s)' treatment of the issue of labeling and traceability, as it would require extensive and different discussions on the effect of framing the public in terms of consumers rather than citizens. To be able to draw conclusions on the state of the Norwegian debate, we only included submissions from Norwegian institutions, organizations, and individuals, and hence excluded the single international submission, which was from the German Federal Office of Consumer Protection and Food Safety. Finally, we note that NBAB organized a series of debate meetings in seven Norwegian cities, as well as one in Copenhagen, Denmark, in order to stimulate public engagement and encourage written responses to the hearing. A video recording of one of these meetings is published on NBAB's webpage (https: / / www. bioteknologiradet.no/2018/08/vi-stroymer-fra-gmo-mote-i-arendal-kl-12-30/, accessed on 6 July 2021), but as no comprehensive visual or textual record of this meeting series is publicly accessible, they are not included in our analysis.

Step one of our method focuses exclusively on D1, uncovering the narrative framing of the issues addressed and revealing the underlying problem representation of NBAB's invitation. Step two focuses exclusively on D2, drawing on poststructuralist policy analysis $[44,45]$ to uncover the way perceived matters of concern support underlying understandings of the problem(s) associated with gene technology and with the GTA in its current 
form. Such problem understandings determine respondents' concerns regarding NBAB's proposal (see Table 1, p. 10). We use the Latourean concept of perplexity to measure and describe the respondents' recognition of yet undiscovered or unknown aspects of genetic phenomena-including their networks of interconnections with other propositions and/or phenomena and how these open up for uncertainties beyond those defined by scientific risk assessment frameworks in GMO regulations. Consultation becomes a measure of the range of actors-human and nonhuman-considered to be relevant in ongoing discussions on gene technology. Respondents' openness to value judgements provides an estimate of their relative acceptance or resistance towards value-based non-safety assessment requirements. Finally, step three compares the results from step two with our analysis of D3 to understand which issues of public concern are reflected in NBAB's final proposal.

In applying Latour's idealized model of public consultation as an analytical framework to evaluate the performance of NBAB in initiating, conducting, and reporting on the public consultation, we develop a clearer understanding of the degree to which the consultation was open, inclusive, and responsive. More broadly, this experimental application of Latour's framework on the case under study aims to promote an innovative and practical perspective on fundamental issues of knowledge construction and the relationship between facts and values that have hampered GMO debates for decades. 
Table 1. Major findings in the hearing responses.

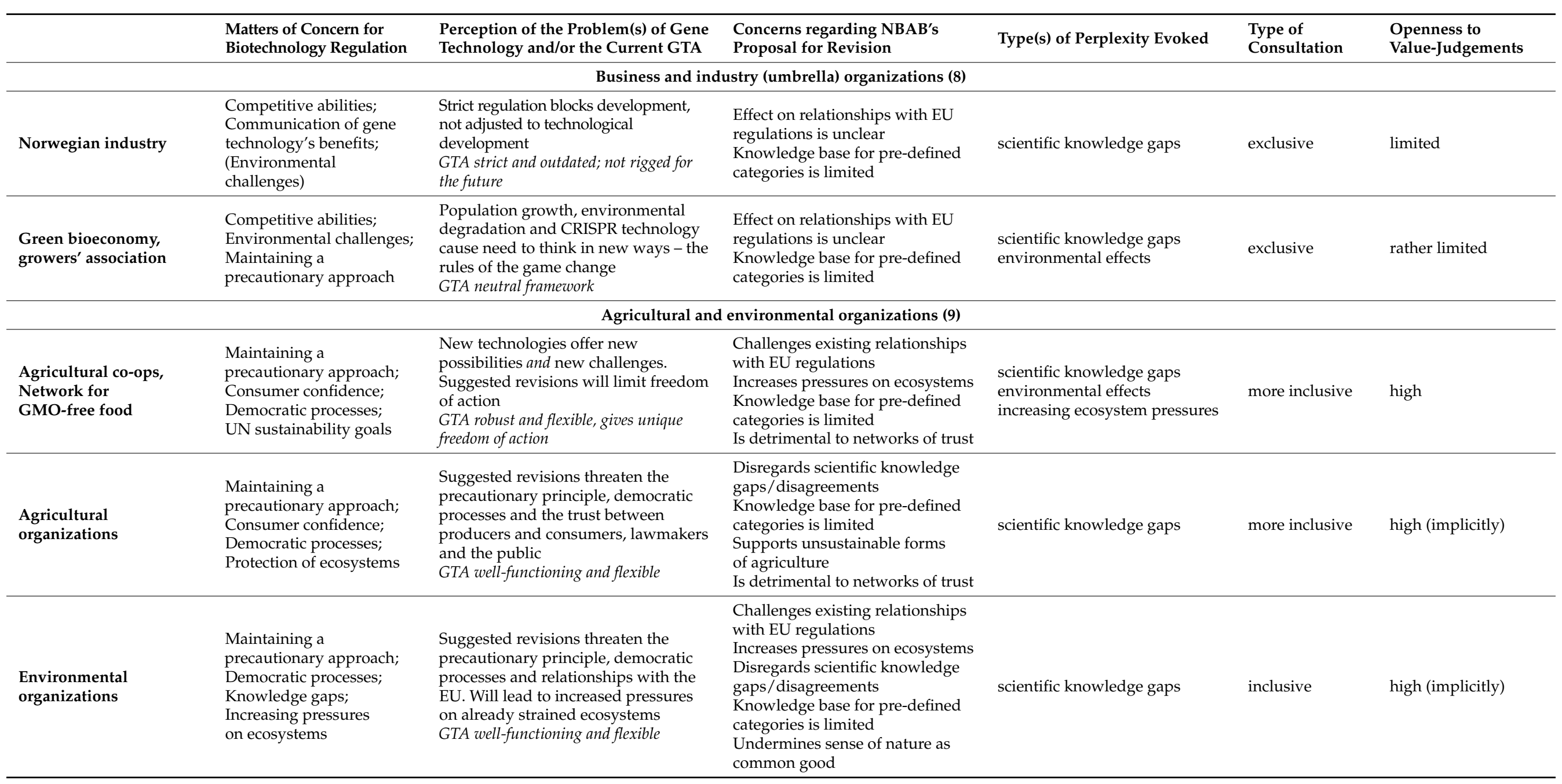


Table 1. Cont.

\begin{tabular}{|c|c|c|c|c|c|c|}
\hline & $\begin{array}{l}\text { Matters of Concern for } \\
\text { Biotechnology Regulation }\end{array}$ & $\begin{array}{l}\text { Perception of the Problem(s) of Gene } \\
\text { Technology and/or the Current GTA }\end{array}$ & $\begin{array}{l}\text { Concerns regarding NBAB's } \\
\text { Proposal for Revision }\end{array}$ & Type(s) of Perplexity Evoked & $\begin{array}{l}\text { Type of } \\
\text { Consultation }\end{array}$ & $\begin{array}{l}\text { Openness to } \\
\text { Value-Judgements }\end{array}$ \\
\hline \multicolumn{7}{|c|}{ Scientific institutions and environments (17) } \\
\hline $\begin{array}{l}\text { Environments of gene } \\
\text { technology } \\
\text { and innovation }\end{array}$ & $\begin{array}{l}\text { Competitive abilities; } \\
\text { Sustainability; } \\
\text { Animal welfare; } \\
\text { Patent rights; Trust }\end{array}$ & $\begin{array}{l}\text { The GTA is 'out of sync' with } \\
\text { regulatory frameworks in other } \\
\text { countries and with scientific } \\
\text { developments and hinders } \\
\text { development. Non-risk criteria } \\
\text { engender regulatory unpredictability } \\
\text { and sense of insecurity } \\
\text { GTA outdated (or neutral); lacks clear } \\
\text { definitions; not rigged for the future }\end{array}$ & $\begin{array}{l}\text { Effect on relationships with EU } \\
\text { regulations is unclear } \\
\text { Knowledge base for pre-defined } \\
\text { categories is limited }\end{array}$ & environmental effects & exclusive & rather limited \\
\hline $\begin{array}{l}\text { Other research and } \\
\text { university environments }\end{array}$ & $\begin{array}{l}\text { Knowledge gaps; } \\
\text { Complexities; } \\
\text { Transparency/trust; RRI; } \\
\text { Environmental challenges; } \\
\text { Competitive abilities }\end{array}$ & $\begin{array}{l}\text { Strict regulation hinders sustainable } \\
\text { development; Subjective non-risk } \\
\text { criteria may block any product: GTA } \\
\text { strict and old; } \\
\text { Suggested revisions are too simplified: } \\
\text { lack analyses of experiences with the } \\
\text { current GTA, of unintended and } \\
\text { detrimental effects on democracy and } \\
\text { relationships of trust, and of increased } \\
\text { pressures on natural environments } \\
\text { and ecosystems: GTA well-functioning }\end{array}$ & $\begin{array}{l}\text { Increases pressures on ecosystems } \\
\text { Disregards scientific knowledge } \\
\text { gaps/disagreements } \\
\text { Knowledge base for pre-defined } \\
\text { categories is limited } \\
\text { Is detrimental to networks of trust }\end{array}$ & $\begin{array}{l}\text { scientific knowledge gaps } \\
\text { environmental effects } \\
\text { increasing ecosystem pressures }\end{array}$ & $\begin{array}{l}\text { varied, mostly } \\
\text { inclusive }\end{array}$ & varied, mostly high \\
\hline $\begin{array}{l}\text { Individual academics/ } \\
\text { academic groups }\end{array}$ & $\begin{array}{l}\text { Change towards } \\
\text { product-based regulation; } \\
\text { Maintaining a } \\
\text { precautionary approach; } \\
\text { Environmental protection; } \\
\text { Search for } \\
\text { alternatives; Trust }\end{array}$ & $\begin{array}{l}\text { Subjective non-risk criteria undermine } \\
\text { objective, scientific risk assessments, } \\
\text { cause unpredictability and may be } \\
\text { used to block any product; GTA } \\
\text { hinders development: GTA strict and } \\
\text { unpredictable; discriminatory } \\
\text { Suggested revisions, and resulting } \\
\text { approval of GMOs in agriculture, } \\
\text { maintain a socio-economic status quo } \\
\text { detrimental to the natural } \\
\text { environment: GTA well-functioning }\end{array}$ & $\begin{array}{l}\text { Increases pressures to ecosystems } \\
\text { (version of) } \\
\text { Disregards scientific knowledge } \\
\text { gaps/disagreements } \\
\text { Knowledge base for pre-defined } \\
\text { categories is limited } \\
\text { Supports unsustainable forms } \\
\text { of agriculture } \\
\text { Is detrimental to networks of trust } \\
\text { Undermines sense of nature as } \\
\text { common good }\end{array}$ & varied & varied & varied \\
\hline
\end{tabular}


Table 1. Cont.

\begin{tabular}{|c|c|c|c|c|c|c|}
\hline & $\begin{array}{l}\text { Matters of Concern for } \\
\text { Biotechnology Regulation }\end{array}$ & $\begin{array}{l}\text { Perception of the Problem(s) of Gene } \\
\text { Technology and/or the Current GTA }\end{array}$ & $\begin{array}{l}\text { Concerns regarding NBAB's } \\
\text { Proposal for Revision }\end{array}$ & Type(s) of Perplexity Evoked & $\begin{array}{l}\text { Type of } \\
\text { Consultation }\end{array}$ & $\begin{array}{l}\text { Openness to } \\
\text { Value-Judgements }\end{array}$ \\
\hline \multicolumn{7}{|c|}{ Other institutions (4) } \\
\hline $\begin{array}{l}\text { The Norwegian Church } \\
\text { Council, ethical } \\
\text { committees, etc. }\end{array}$ & $\begin{array}{l}\text { Maintaining a } \\
\text { precautionary approach; } \\
\text { Environmental protection; } \\
\text { Protection of the less } \\
\text { resourceful; Value and } \\
\text { inviolability of God's } \\
\text { creation; Anthropogenic } \\
\text { environmental changes; } \\
\text { Need for human } \\
\text { stewardship; Discursive } \\
\text { framing; Knowledge gaps }\end{array}$ & $\begin{array}{l}\text { Gene technology is dominated by } \\
\text { large international corporations that } \\
\text { do not have people's best interest in } \\
\text { mind; Systemic pressures against } \\
\text { God's creation are increasing and } \\
\text { alternative solutions are necessary to } \\
\text { protect its most vulnerable members; } \\
\text { Scientific uncertainty and ignorance } \\
\text { are easily under-communicated; Being } \\
\text { against gene technology is not a } \\
\text { legitimate option: GTA well-functioning }\end{array}$ & $\begin{array}{l}\text { Challenges relationships with } \\
\text { EU regulations } \\
\text { Increases pressures on ecosystems } \\
\text { Disregards scientific knowledge } \\
\text { gaps/disagreements } \\
\text { Knowledge base for pre-defined } \\
\text { categories is limited } \\
\text { Supports unsustainable forms } \\
\text { of agriculture } \\
\text { Employs rhetorical } \\
\text { discursive strategies }\end{array}$ & $\begin{array}{l}\text { scientific knowledge gaps } \\
\text { environmental effects } \\
\text { increasing ecosystem pressures }\end{array}$ & $\begin{array}{l}\text { inclusive } \\
\text { (implicitly) }\end{array}$ & high \\
\hline
\end{tabular}

Other individual responses (8)

Change towards

product-based regulation

Communication of gene

technology's benefits;

Environmental challenges;

Maintaining a

precautionary approach;

Scientific reductionism;

Knowledge gaps; Search

for alternatives
The GTA is too strict and unpredictable

because founded in politics and social

constructions, and it hinders

development; Non-safety criteria are

flawed and should be removed: GTA

strict and unpredictable; unnecessary

Strong business interests, financing of

research, research methods and choice

of evidence provide a skewed image

of reality: Gene technology alters time

perspective of evolution alters tim

perspective of evolution and may

Reductionist scientific thinking not

equipped to handle the complexitie

of gene modification: GTA

well-functioning and future oriented,

protects research and consumer interest
Increases pressures on ecosystems

(version of)

Knowledge base for pre-defined

categories is limited

varied

varied

varied 


\section{Results}

This section is divided into three subsections that correspond to our three-step analysis. The first presents findings from the analysis of D1 and reveals NBAB's framing of the public consultation. The second presents the findings from our analysis of D2, the consultation submissions. Finally, Section 3 reveals the degree to which public concerns were reflected in D3, NBAB's final proposal.

\subsection{NBAB's Framing of the Debate (D1)}

Our analysis of D1 reveals how NBAB's draft proposal to relax the Gene Technology Act frames (a) GMOs as an economic opportunity to be harnessed, (b) naturalness as a concept that justifies regulatory relaxation, (c) genome editing techniques as beyond ethical consideration, and (d) ethical issues as separate from practical work with gene technology.

NBAB's framing relies heavily on two proposed models for regulatory relaxation on which consultation participants were asked to comment. Model 1 (D1, p. 27) is NBAB's preferred model and is the more radical, designed to reduce long and unpredictable assessment procedures. It relies on ranking the genetic changes into three levels: Level 1 involves changes that could occur naturally or through conventional breeding methods, level 2 includes organisms with species-specific genetic changes, and level 3 refers to organisms that include cross-species genetic changes or involve synthetically designed DNA-sequences. In Model 1, many genome edited organisms would undergo simplified impact assessments. Only products on Level 3 would be subject to the assessments and approvals of the current system, which includes public consultation.

Model 2 is less radical in the sense that it maintains the original process-based and precautionary approach to regulation. Here, the non-safety assessment precedes scientific risk assessment. A differentiation is made between products with strong (level 1), moderate (level 2), and poor (level 3) ethical justification (D1, p. 34). Applications at level 1 may undergo simplified risk assessments, whereas those on level 2 follow existing regulatory processes. Applications for GMOs categorized in level 3 will be rejected, making costly and time-consuming procedures of risk assessment unnecessary. Model 2 specifies that not only the genetic changes made to an organism, but also the process of modification, its associated uncertainties, and available alternatives are aspects relevant to ethical justifiability. Ethics is understood comprehensively as "concerned not only with articulating and avoiding what is bad, but also understanding and promoting what is good" (D1, p. 34).

\subsubsection{GMOs as an Economic Opportunity to Be Harnessed}

The observation that Model 1 is NBAB's preferred model is based on its alignment with the basic framing of the consultation (D1). NBAB's aim is to "develop appropriate and robust regulatory frameworks that facilitate the harnessing of the potential of gene technology, while also avoiding harm to health and the environment, and promoting sustainability, societal benefit and ethics" (D1, p. 3). Presuming that the bioeconomy will rely on technological innovation, NBAB imagines that the GTA "will define the framework for the use of gene technology in the future bioeconomy, and positive and negative consequences of the different alternative forms of regulations should [therefore] be weighted against each other" (D1, p. 6 [sic.]). It points to the negative consequences of process-based regulation, citing studies showing that the average EU GMO application assessment took nearly five years and cost producers between USD 10-30 million (D1, p. 26). This frames the underlying problem of current GMO regulation as one that hinders gene technology research and economic development. In presenting GMOs and genome edited organisms as an economic opportunity to be harnessed, NBAB implies that the GTA blocks the development of potentially sustainable, socially beneficial, and ethically sound products in Norway. What allows this blockage is the GTA's process-based approach to regulation, which through the precautionary principle actuates non-safety assessment criteria that can be used to overrule scientific risk assessments. NBAB's position reflects that of gene 
technology developers and supporters who have long argued that the GTA's process-based approach is old fashioned and in need of revision.

\subsubsection{Naturalness Justifies Regulatory Relaxation}

According to the GTA, a GM organism is "a microorganism, plant or animal in which the genetic material has been altered by means of gene or cell technology" [1] (Article $4 \mathrm{~b}$ ). This is different from the EU Directive's definition of a GMO as an organism "in which the genetic material has been altered in a way that does not occur through natural reproduction and/or natural recombination" [4] (Article 2.2). NBAB nevertheless frames GMOs on a scale of "naturalness" to allow some to bypass regulatory scrutiny. Claiming that Norwegian legislation rests on a distinction between what can and cannot occur naturally/in nature, it promotes two arguments that rest on the fuzziness of this concept. The first is that genetic modifications utilizing the naturally occurring processes of making mutations may be considered "natural" (D1, p. 12). The second relies on conceptualizations of naturalness as a continuum of degrees (D1, p. 12) to argue for a graded regulatory regime that differentiates between GMOs identified as more or less close to "the natural." In support of this, NBAB refers to the EU's report from May 2017, "New techniques in agricultural biotechnology," which concludes that the "variety and versatility" of new techniques of genome editing means that grouping them together "may not be optimal for scientific or other reasons" [46] (p. 17), (D1, p. 14). NBAB's discussion of naturalness thus establishes a parallel between the regulatory tiers of Model 1 and degrees of property-based forms of naturalness. It does this by evoking naturalness as a foundation for legislation, although this is not the case in Norway (unlike in the EU), and through selective use of theoretical work on the concept of naturalness [47]. Significantly, this selectivity involves ignoring discussions of history- and relation-based dimensions of naturalness present in NBAB's source [47], which are of high relevance to the ethical aspect of the GMO debate [36].

\subsubsection{Genome Editing Techniques as beyond Ethical Consideration}

The way in which genome editing is framed in D1, as a controllable form of molecular biology, weakens the argument of non-safety considerations and lends further support for Model 1. For example, NBAB presents background information on different gene technologies in a fact box that downplays the distinction between conventional forms of breeding and old forms of gene technology (D1, p. 8-9). "Conventional" breeding techniques involving the modification of genomes yet exempted from regulation (mutagenesis, triploidization, and cell fusion) are presented in ways that emphasize human intervention in living cells using radiation, high pressure and temperatures, enzymes, and other chemicals. Similarly, descriptions of older, "classic" forms of gene modification reveal the use of virus and bacteria, chemicals, electricity, microinjections, or gene cannons on living cells. In contrast, newer forms of genome editing methods are framed strictly at the molecular level. Indicating that only target genes are affected, NBAB presents a classic molecular-biological framing that purifies the new techniques of gene technology ([32] (p. 135); [48] (p. 10)) by presenting its scientific facts as separate from human agency and stresses its precision and predictability. Potentially ethically challenging forms of human intrusion slip away, preparing the ground for neglecting the processes of manipulation and treating the products of this technology like any other manufactured product. The conspicuous lack of corresponding fact representations of unintended and/or potentially harmful effects of the presented genome editing methods serve the same function. In this manner the invitational report's (D1) presentation of the facts of gene technology subtly contests the GTA's process-oriented definition of new, genome edited GMOs.

\subsubsection{Ethics as Unconnected or Secondary}

The invitational report (D1) at several instances declares NBAB's unanimous agreement to maintain the principle of assessment of criteria for sustainability, societal benefit, 
and ethics (D1, pp. 4, 41, 42). This open support of non-safety considerations is nevertheless undermined by the report's abstract representation of ethical approaches. The report presents in some detail different ethical positions that may form the basis of ethical assessments (D1, p. 18). However, no indication is given of what difference it would make to apply the principles of care ethics rather than a consequentialist framework on the assessment of GMOs. Unlike arguments in favor of gene technology, ethical positions and arguments are not connected to real-life examples, and readers learn nothing about the kind of ethical challenges researchers and producers face as they work towards products like hornless cattle or sterilized salmon for aquaculture: challenges of balancing benefits with drawbacks and of assessing in what ways and for whom the methods and changes involved may have ethical consequences. A fact box lists examples of traits under development (D1, p. 17), but the categories listed are all positive and the connection between "good" products and positive ethical judgement is hinted at rather than openly asserted and critically discussed. This tacit positive ethical framing of the new gene technologies arguably works in support of the report's economic framing of the issue of GMO regulation and hints of a need to rework the possible impact of the non-safety assessment criteria based on economic and scientific realities.

Overall, NBAB's draft report and call for public consultation (D1) frames the case for regulatory relaxation of genome edited organisms by emphasizing their economic potential, foregrounding their naturalness, presenting genome editing techniques within a paradigm of molecular biology highlighting their pure scientificity and precision, and maintaining a separation between (abstract) ethical positions and the practical utilization and consequences of the new technologies. The chapter entitled "Sustainability, societal benefit and ethics-important considerations" begins not with an explanation of how and why these considerations are important but with a discussion of the societal consequences of different regulatory systems that highlights how "disproportionately strict" regulatory systems make product development "unpredictable, time consuming and expensive" and restrain the competitive abilities of Norwegian actors in international markets (D1, p. 16). It moreover suggests that "product traits" rather than "production process" are what determine the sustainability, societal benefit, and ethics of GMOs (D1, p. 16). The last chapter of NBAB's invitational report, entitled "Sustainability, societal utility and ethics: How much is sufficient?" is less than a page (D1, p. 41). Maintaining that "one might question whether it is necessary to require GMO products to having to contribute to increased sustainability and societal benefit, since other products are not subject to such requirements for approval," NBAB's report both in form and content suggests that a little ethics is enough (D1, p. 41 [sic.]).

\subsection{Major Trends in Responses to the Hearing (D2)}

This section presents the results of the discourse analyses of the consultation submissions (D2) in step two. Table 1 summarizes these findings and is organized around three substantive clusters of actors: (a) business and industry, (b) agricultural and environmental organizations, (c) scientific and research institutions (including responses submitted by academics independently of their institutional affiliations [see Table A1]), and two smaller clusters-(d) other interests/organizations, and (e) individual responses. Below, we discuss these findings for the three main actor clusters. We list responses from the two smaller clusters in Table 1 only.

\subsubsection{Business and Industry Actors (8 of 46 Responses)}

The perception of what constitutes the underlying problem concerning the regulation of gene technology varies according to the position and power of the respondents. Umbrella organizations representing Norwegian business and industry support NBAB's problem framing, arguing that the GTA restricts their access to international markets and that they are falling behind in comparison to international competitors. 
Two actors in this group highlight Norway's competitive advantage based on "its restrictive use of antibiotics and pesticides, its focus on animal welfare, health and fertility," and its GMO-free production lines. However, as more countries make use of CRISPR technology, they believe power relationships built on competence will shift, and the possibility to maintain the competitive advantage built on successful and systematic long-term work in traditional breeding and food production will disappear. The underlying problem is the new competitive premises of the market generated by the genome editing technologies. They nevertheless adhere to the views of the rest of the group in perceiving a revision of the GTA necessary to solve the problem.

Many actors in business and industry believe gene technology can address environmental problems; however, they focus on economic sustainability such as improvements to production processes to reduce waste and better animal health. In framing genome editing as an enabling technology to propel economic development and environmental sustainability, such actors argue for speeding up research and innovation and support legislative revisions that make this possible. A technologically uninformed and prejudiced public, giving GMOs a "sordid reputation" and opposing "knowledge-based" decisions regarding commercial use, emerges as a significant risk factor. Unsurprisingly, these business and industry actors are not supportive of broad democratic involvement. Instead, they imagine the processes of consultation as exclusive both in terms of forms of knowledge and actors involved.

\subsubsection{Agricultural and Environmental Organizations (9 of 46 Responses)}

Agricultural umbrella organizations call for a better balance between international competitiveness and the need to maintain a precautionary approach. Like other agricultural organizations, they find NBAB's relaxation proposal problematic and worry about the well-being of small Norwegian actors if deregulation opens up competition from an international market of GMOs. Norwegian legislation is interpreted as offering the freedom to refrain from using gene technology in food production. This freedom is unique in an international context and relies on the GTA's precautionary approach and inclusion of non-safety assessment criteria, through which Norway has negotiated an exemption from EU legislation. Agricultural organizations accordingly emphasize the already existing flexibilities of the current legislative framework.

Agricultural and environmental organizations alike are critical of Model 1 because the removal of public consultations for level-1 and -2 applications threatens carefully built systems of trust between producers, consumers, and authorities, which remain important for democratic as well as economic reasons. They support consultation that includes a broader range of (human and nonhuman) actors than business and industry organizations and raise concerns that regulatory relaxation may threaten both democracy and nature. These organizations share an environmental concern about the "balance" of natural ecosystems and how GMOs might impact the structural dynamics of complex, open systems. The behavior of such systems is marked by radical forms of uncertainty $[49,50]$ and evokes perplexities. Agricultural and environmental organizations raise concerns that regulatory relaxation may result in a significant increase in approved applications for commercial use, thereby placing more pressure on already stressed ecosystems. Uncertainty about the impacts of new genome editing techniques means that these new risks may be larger than the risks associated with traditional GMOs. They take issue with NBAB's claim that small genetic changes cause small (genetic) effects and argue the knowledge needed to establish the biologically based categories on which Model 1 rests does not exist. The sense of perplexity these organizations evoke is thus more pronounced than for organizations representing industrial interests. Fearing that regulatory relaxation through legislative change will be an irreversible process of cascadic (and negative) social, economic, legal, and ecological consequences, these actors implicitly seek the protection of both nature and the law. 


\subsubsection{Scientific and Research Institutions ( 17 of 46 Responses)}

Scientific environments using gene technology for research and innovation purposes, as well as a few university bioscience environments, follow NBAB in identifying a strict and outmoded GTA as the problem to be tackled. Other scientific environments point out biological/ecological and bureaucratic complexities that challenge NBAB's proposal and indicate a need for openness towards risks not yet identified and for active research involving more expansive forms of causality than those imagined within the framework of molecular biology. In describing the novelty of genome editing, such actors highlight new processes detected in genomes and cells, and new relationships between genotype and phenotype and between molecules within the targeted cells. Against the narrative of gene editing as more efficient and accurate, they evoke perplexities such as unintended effects, knowledge gaps, uncertainty, and scientific disagreement. Some call for gene technology research in different contexts and environments of use, arguing that this research has been tendentious in focusing more on the possibilities than on the unintended and possible problematic effects of the use of new technologies.

These actors challenge NBAB's differentiated assessment system based on genetic changes in Model 1. One actor maintains that the alleged simplification of bureaucratic processes involved in NBAB's proposal is in fact merely a matter of simplified representation; of not properly describing the complexity of bureaucratic processes that would be involved in the safe assessment and possible release of GMOs into the environment also in Model 1. Another actor points to how NBAB's apparent lack of competence in evolutionary biology causes it to operate with an obsolete definition of "species" and an outmoded understanding precisely of what is "natural" in the transfer of genes between species. Highlighting the agency of nature in a way that implicitly questions the biological foundation for the differentiations of NBAB's Model 1, this respondent is deeply concerned that NBAB's application of premises that lack scientific accuracy causes the entire discussion to proceed on false grounds. Furthermore, it accuses NBAB of a one-sided, forward-looking focus that by ignoring the complexities of naturally occurring processes of evolution can introduce the processes of the gene technology as novel and in immediate need of harnessing.

Half of the submitted responses from this actor group suggest that NBAB's proposal undermines democratic processes and established relationships of trust, particularly trust in science. One actor views the GTA's precautionary approach as a guarantee for responsible research and innovation (RRI). Another argues that public suspicion that new legislation is "controlled by a power elite of selected academics and a financially strong industry with obvious self-interests" could generate distrust in science and research institutes. These are compelling reasons to support existing consultation processes in the GTA. Moreover, the fear of "falling behind" should not stop inclusive and democratic involvement in the legislative revision process. Spending time on these issues (like the EU has done) is not necessarily a bad thing, as processes of liberalization might in retrospect be difficult (if not impossible) to reverse.

There is division on the matter of non-safety assessment criteria among scientific actors. The majority want non-safety assessment criteria (sustainability, societal utility, and ethics) to remain within the GTA, but many of them agree with NBAB's tier-based differentiation of these criteria, as proposed in Model 1. Those in favor of maintaining them unaltered point to the tremendous biological, bureaucratic, and democratic complexities of gene technology research, and express the value of non-safety assessments for responsible research. Those critical of these criteria argue that they turn the GTA into a "discriminatory" form of legislation that hinders the development of one specific product. Some scientists find the ability of non-safety assessments to undermine objective, scientific risk assessments even worse than the law's discriminatory practices. They advance claims of objectivity to maintain non-safety evaluations as separate, purely normative evaluations that come after or are subsumed into the more important, more objective, and somehow truer scientific evaluations of risk. Ethical concerns are dismissed as "fuzzy" and subjective, and the precautionary principle becomes a "status quo bias." For such actors, the scientific and 
technological become associated with progress and development and support the greater good for humanity. Political and ethical concern is framed as blocking this development.

\subsection{The Final Proposal (D3)}

In the final "Proposal for relaxation," NBAB maintains that all GMOs should be regulated by the GTA, allowing authorities to maintain overview and control as biotechnology innovations intensify in pace and scale. It nevertheless highlights the need for differentiated regulation based on a principle of method-independent and equal treatment of organisms with similar genetic traits. In practice, NBAB's proposal for differentiated regulation (Model 1) means that GMOs on level 1 (with changes that could occur naturally or through conventional breeding methods) will be subject neither to standard risk assessments nor to public hearings. NBAB's final report strengthens the already established framing of gene technology as a safe technology that should not be discriminated against, for example by deleting descriptions of the randomness and unintended effects of older forms of gene technology in its fact box on genetic engineering techniques (D3, p. 13); by emphasizing how the impact of unintended changes varies between different kinds of organisms and are minimized in plant breeding (D 3, p. 15); and by adding an extra example from salmon aquaculture of how sterile salmon produced through conventional but gene-manipulatory forms of breeding (causing triploidity) are regulated less strictly than (seemingly healthier) gene edited salmon (D3, p. 17). The report furthermore presents developers' difficulties in providing documentation of the non-safety aspects of their GMO products as arguments against non-safety assessments (D3, p. 28). In accordance with these and similar perceived needs for legislative revision, NBAB recommends the establishment of an official committee to review the GTA and "consider different ways of differentiating and simplifying the processing of applications for deliberate release of GMOs" (D3, p. 4).

\subsubsection{The Fate of Critical Concerns}

Figure 1 gives an overview of the fate of arguments critical to NBAB's proposed revision of the GTA. Briefly summarized, we find that respondents' concerns about the effect of the proposed legislative revisions on carefully built relationships of trust (between producers and consumers, the public and the authorities), about scientific knowledge gaps and perplexities, about the environmental and socio-economic impact of current production systems, and about the state of nature as a common good are in the final report treated either in contexts in which their full impact are reduced to technical issues (trust issues become a matter of labelling) or rendered scientifically irrelevant (scientific knowledge gaps become a matter of ethics)—or not treated at all.

\subsubsection{The Fate of Naturalness}

NBAB to some extent amended the final report in response to critique about its use of the concept of naturalness. From among the scientific and philosophical discussions of this concept provided by respondents, they chose to include arguments about the natural variation and transfer of genes across species and use these to claim that "mutations and gene flow between individuals and species both occur naturally and is a driving force for evolution. Viewed in this way, it may be problematic to classify one genetic change produced through genetic modification as being more unnatural than another genetic change" (D3, p. 16). Problematizing the concept of the species only to the extent that it poses problems to the distinction between proposed regulatory tiers, NBAB re-frames an inherently critical response in a way that naturalizes the products of gene technology while leaving out the larger question of how its own use of the species concept [51] shapes the debate. Nothing is mentioned of the need for competence enhancement within NBAB or for alternative evolutionary or relational perspectives on gene technology. 


\section{The fate of arguments critical to the NBAB's proposed revision of the GTA}
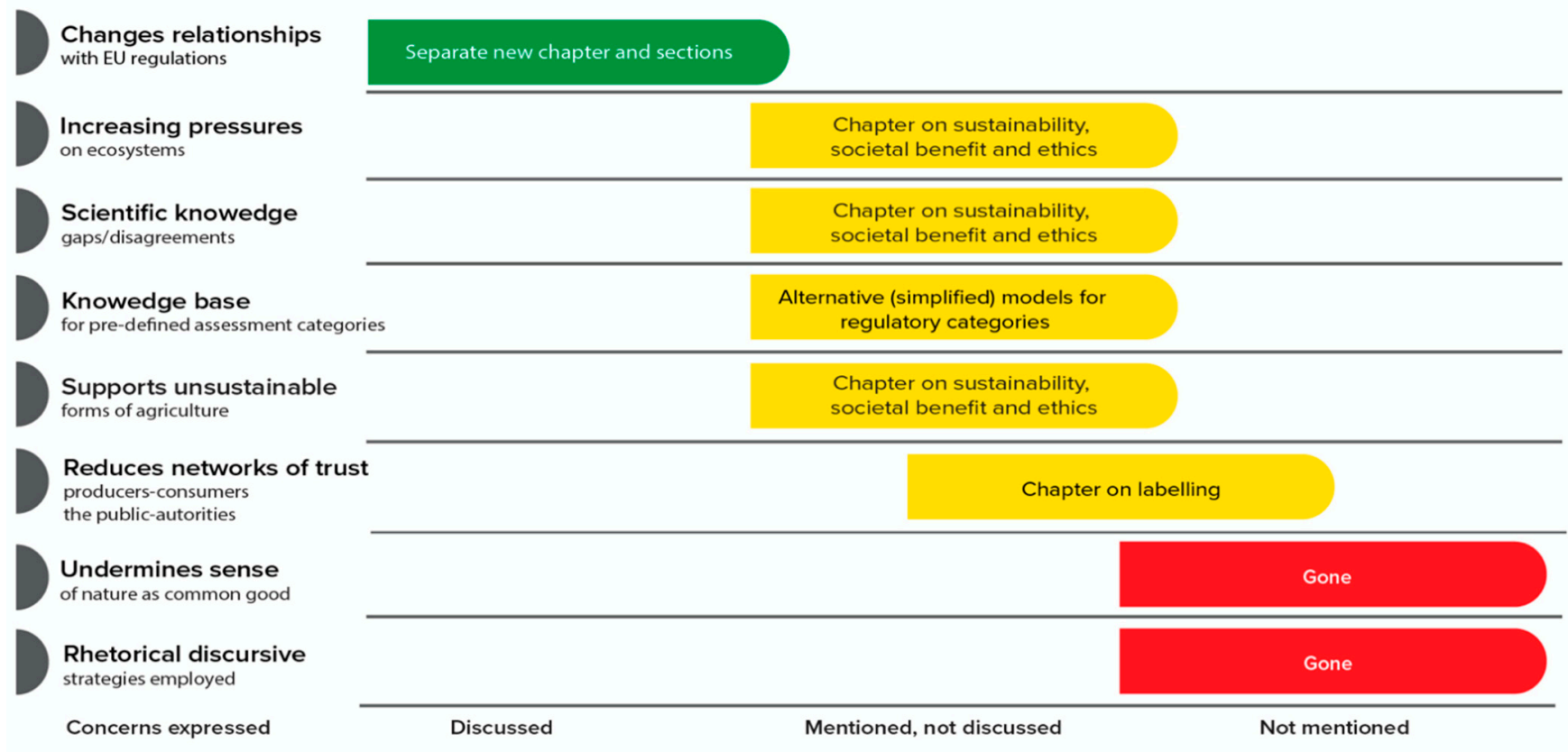

Figure 1. Overview of the fate of major concerns issued by respondents in NBAB's final "Proposal for relaxation".

\subsubsection{The Fate of Environmental Concerns}

The separation of facts and values that is present in the invitational report is strengthened in the final report. The claims of agricultural and environmental organizations that a general lack knowledge of the unintended effects of gene technology necessitates a continued precautionary approach are reported in the chapter "Sustainability, societal utility and ethics." Facts of knowledge gaps or scientific controversies, genetic transfers, and accumulative pressures to ecosystems in this way appear to fall in a different category than the methods and products of the "purified" technology [48]. Unlike assessments of health and environmental risks performed by scientists and developers of gene technology, knowledge of actual and possible environmental effects, scientific uncertainties, and disagreements emerging from other actors appears neither as directly connected to the use and development of the technology itself nor as truly scientific.

Where concerns regarding environmental effects, scientific uncertainties, and disagreements are mentioned in NBAB's final report (D3), they are immediately neutralized by claims of how gene technology may offer unique improvements in the sustainability of aqua- and agricultural production chains. Indeed, the final report is somewhat confusing because advantages of the new technologies are interwoven in discussions of challenges and disadvantages, whereas the reverse does not occur.

\subsubsection{The Fate of Ethical Assessments}

The most striking difference between the invitational (D1) and the final (D3) report, however, is that in the final report Model 2 is relegated to the appendix and no longer represented as a realistic alternative form of differentiated regulation. Two new models based on genetic change but with fewer tiers take its place (D3, p. 41), and ethical defensibility is mentioned last and most briefly (after potential for spreading to the environment and experience of use) in a new fact box listing possible further differentiations (D3, p. 42). With this, actual criteria for the assessment of sustainability, societal utility, and ethics both visually and textually disappear, making it even more difficult to associate ethical approaches with concrete cases. In the final report, the Invitation's brief chapter entitled "Sustainability, societal utility and ethics: How much is sufficient?" (D1, 42) is further abbreviated and the rather telling subtitle is edited out (D3, p. 49). Out of the 60-page long 
final report (not including annexes) submitted by the NBAB to the Ministry of Climate and Environment, a mere four-and-a-half pages deal specifically with issues of sustainability, societal utility, and ethics.

\section{Discussion}

\subsection{European Legislation Becomes Part of the Problem}

In its 2017 "Invitation to public debate" (D1), NBAB established an economic framing of the question of gene technology regulation that caters primarily to the interest of business and industry actors and market-oriented scientific environments. This framing follows quite closely what Macnaghten and Habets [11] (p. 356) identify as the "historical narrative" used by agrochemical companies and research organizations who argue that licensing is time consuming, expensive, and hampers innovation. NBAB chose to maintain this framing even after the European Court of Justice on 25 July 2018 clarified the scope of the European GMO Directive by judging that all organisms altered by mutagenesis methods or techniques-including all products of genome editing-are subject to the Directive's regulations [52]. Arguably, this alleviates Norwegian actors' concern of falling further "out of synch" with the legislation of genome edited organisms in Europe. The fact that NBAB makes no direct reference to this important change in its final report (D3), only tacitly including EU legislation as part of the problem, signals its ardor to relax current regulatory regimes.

\subsection{Scientificity and "Objectivity" Promote Legislative Relaxation}

NBAB appears to make room for a broad discussion on gene technology and its ethical and societal implications in its report(s) (D1 and D3). Yet NBAB's framing strategies, forms of representation, and bias in favor of scientificity (the quality of being scientific) and "objectivity" all question process-based forms of regulation and promote its model for differentiated regulation based on genetic change. Discussions on the definition of "the natural," for instance, suggest-contrary to the European Court of Justice's interpretation [52]—some genome edited organisms may be considered natural and therefore beyond the scope of the EU's definition of GMOs. Moreover, arguments related to scientific and technological facts appear to be included in the final Proposal (D3) to the extent that they support legislative relaxation, downplay the unintended effects and inefficiencies of gene technology, and promote the relative preference of new methods of genome editing over old ones. Arguments critical to NBAB's suggested Model 1 (D1, p. 27), for instance, regarding the state of knowledge on which the definition of assessment categories will depend, are not explicitly dealt with in the final report. Although this specific (and quite fundamental) concern is voiced by all category actors, NBAB only responds by further simplifying its model for differentiated assessment based on genetic change by reducing the number of tiers from three to two (D3, p. 41).

\subsection{Allegations of Discrimination Support Product Regulation}

Given the way NBAB's reports (D1 and D3) tacitly imply research and development as the only sensible way forward, the resistance of several actors against non-safety assessments is not surprising. Arguably, NBAB's Invitation (D1) provides an argumentative platform for scientists who accuse non-safety assessments of turning the GTA into a discriminatory form of legislation that hinders development. Such allegations of injustice rely on direct comparisons between individual GMO and non-GMO products. The modern narrative of individual rights is activated on behalf of GMOs as one among many possible category products, and the right to equal treatment under the law is associated with the legal right of products to enter the open marketspace, not with the legal rights of living beings selected for modification and subsequent productification. Curiously, this approach, which is discriminatory when applied to GMOs, is in turn used on gene modifying techniques characterized as conventional to set them apart from the new genome editing technologies. This reveals how the concept of GMOs in the discourse on gene technology 
becomes differentiated or not according to context, discursive positioning [53], and, in NBAB's reports, in accordance with a felt need for more product-based approaches and a subsequent relaxation of current regulation.

NBAB aims for a re-definition of GMOs and a revision of current legislation towards a product-based regulation inspired by North American regulatory frameworks. Within such frameworks, science is given great defining power over further innovation and is regarded as the carrier of progress and humanitarian endeavors cf. [32], and governmental control over legislation is understood to obstruct or render impossible such endeavors [27]. Despite several respondents' dismissal of "the ethical" model for regulation, the hearing reveals that this interpretation of the government's role in innovation is foreign to many Norwegians. This is particularly the case for environmental and agricultural organizations who consider it the task of Norwegian government and legislation to protect the health of Norwegian ecosystems, the culturally deep-founded status of nature as a common good, and the uniqueness and market value of already existing products of agri- and aquaculture (See Table 1).

\subsection{Fact-Value Distinctions Minimize the Role of Ethics}

NBAB's two reports (D1 and D3) appear to reinforce existing and problematic divisions between scientific facts and societal, political, and ethical values, and assign more power to techno-scientific environments over the development and use of gene technology. Factvalue distinctions seem to determine the strategic inclusion and treatment of respondents ${ }^{\prime}$ arguments and concerns in the final report (D3), but in this connection, legal and economic concerns are treated like facts. Economic concerns constitute the major framing of issues under discussion, and respondents' critique concerning the legal repercussions of the presented regulatory revisions are met by adding an extra chapter to the final report on "Flexibility under current regulations" (D3, p. 50).

NBAB could have chosen to address concerns expressed by agricultural and environmental organizations and many scientific environments by explaining ethical frameworks in more detail and relating them to practices in laboratories and in agri- or aquaculture production lines. Instead, its final report (D3) sidelines ethical problems and discussions along with its ethical Model 2 (D1, p. 34). This makes it even more difficult to associate ethical approaches with concrete cases and edits out the idea of political/ethical control over the direction of technological development. As scientific processes are "purified" and kept separate from ethical questions, concerns regarding the under-communication of perplexities or research focusing more on the possibilities than on the possible problematic effects of the new technologies find no grounds for support-even when posed from within scientific communities (D2). Such ethical considerations remain suspended above discussions of the scientific details of the new technologies under development and become only vaguely expressed in respondents' calls for more-and more independent-research. NBAB's discussion of the ethical and societal concerns remain vague and abstract, except when in favor of new GMOs, thereby restricting open and frank debate.

\subsection{A Latourean Framework Highlights Gaps between Mandate and Practice}

What makes this negligent treatment of ethical questions both curious and problematic is the complexity of NBAB's mandate and function. In addition to providing advice on matters concerning the use of biotechnology, NBAB is given special responsibility for the processes of consultation: making sure all voices are heard and all matters of concern are aired in the complex decision-making on whether and how to include GMOs in the Norwegian collective (D1, p. 2). In Latourean terms, NBAB thus performs a political function with great potential to broaden knowledge construction. However, with its officially assigned role in providing the government with recommendations on the nonsafety aspects of GMO applications, NBAB is also the designated philosopher/moralist of the Norwegian regulatory system. This role is not made clear in either report (D1 or D3). 
In Latour's model for political ecology, philosophers/moralists serve two important functions. One is to evaluate and place into one common hierarchy the different values and matters of concern expressed within the collective. The other function, significant to our analysis, is to constantly question the status quo, thereby allowing new (or previously rejected) natural-cultural entities to (again) be considered candidates for possible membership in the good, common world [28] (pp. 156-158). Philosophers/moralists are thus-like scientists evoking perplexity-important in involving the political-ecological collective in constant and iterative trials for inclusion. However, in order for this recursivity to have a purpose, consultations must proceed and be recorded fairly. According to Latour, the procedural expertise of administrators/bureaucrats is what prevents "all the powers, all the partial competencies, from interrupting the exploration of the learning curve, or from dictating its results in advance" [28] (p. 206). In this manner, responsibility for the ethical foundation for discussion within the collective is shared between philosophers/moralists, scientists, politicians, and administrators/bureaucrats.

Through its "Invitation to public debate" (D1), NBAB aims to fulfill its political responsibility to bring out a broad array of relevant voices and witnesses to debate what GMOs are and could become, and how they may come to impact the collective. NBAB brings the case of genome editing before the decision-making processes of the collective on the argument that their characteristics have changed in fundamental ways. As such, it performs well the philosopher/moralist's task of keeping the political-ecological collective in an open and ongoing process of composition, albeit in a manner that seems particularly sensitive to the competitive needs of gene technology science and industry. (Noteworthy in this respect is that unlike scientists within other environmental sciences-for which Latour developed his model—geneticists and molecular scientists not only identify, but also engender and may come to significantly benefit from the candidates for common existence which they propose as members of the common collective.) What we find problematic is the way NBAB maintains a strict separation of facts and values that hampers a proper discussion and ranking of values. By allowing the fact-value distinction and molecular biology's "safe enough" framing to limit the contribution of other forms of knowledge in the construction of the facts of gene technology, these other forms of knowledge remain irrelevant to definitions of the state of the world on which value discussions on gene technology proceed. In NBAB's report(s), this applies whether the knowledge in question concerns the actual (technical) application of new gene technologies in the lab or the state of the (natural) world outside it.

On the bases of the many framing strategies applied in the presentation of "the problem" of GMO regulation, NBAB appears to perform poorly its responsibility to engender an open, inclusive, and transparent form of consultation in which different actors participate on equal terms. Our Latourean perspective reveals this to be an epistemological as well as a democratic problem. In the final report (D3), NBAB's emphasis on narratives of techno-scientific development favors respondents with the narrowest sense of what constitutes proper consultation on gene technology. In so doing, it neglects perspectives from respondents with more complex and inclusive understandings of the common world and the place of GMOs within it. This is unfortunate, as a recent Norwegian survey revealed positive attitudes toward genome editing technologies if they promoted sustainability, promised societal benefits, did not negatively impact animal welfare, and if they were developed, used, and regulated in Norway [14]. A high level of trust in the ethical soundness of both the production and the regulation of GMOs seems thus vital to Norwegian consumers' acceptability of new gene technologies. Accordingly, careful deliberations on the non-safety aspects of the use of these technologies must be performed to prevent their introduction from happening at the expense of the public's trust in Norwegian producers and authorities.

NBAB frames a change in the GTA as a matter of regulatory practice. It engages primarily in issues believed to make the practical part of regulatory assessments easier and more predictable for developers. Yet it also leaves aside proper discussions of concern 
for the integrity of living beings, single and accumulative effects on ecosystems, current practices of industrialized aqua- and agriculture, and nature-culture relationships. In doing so, it treats the associated radical uncertainties negligently and lets the discussion proceed comfortably and uncritically within the framework of current science policy culture. Furthermore, NBAB fails to seriously open up to broader forms of knowledge construction and cross-disciplinary collaborations capable of addressing more complex forms of scientific, ecological, and cultural perplexities. NBAB's suggestion is for a regulatory system that is rigged to treat GMOs not as individual and exceptional applicants to membership in the collective, but as already accepted members for whom we need practical procedures for speedy inclusion, accommodation, and (hopefully) monitoring. NBAB notes, but does not seriously consider, the fact that agricultural and environmental organizations find the combination of regulatory and technological efficiency threatening in itself. There is no room for a critique of the system in NBAB's report(s).

NBAB's report(s) have elements of what Jasanoff et al. have described as "choreographed conversations on issues experts have predetermined to warrant debate" in which "speaking the right language, that of scientific rationality," is necessary in order to engage in deliberative democracy [29] (p. 32). As a small milk farmer's cooperative perceptively pointed out in its hearing response, NBAB's report creates the sense that "being against the use of gene technology is not an option." Through some very subtle use of rhetoric and forms of representation, the basis for such alternative and critical value-based evaluations has been rendered negligible to the extent that their expression becomes almost impossible.

\subsection{GMOs at the Heart of Political and Value-Laden Projects to Construct a Good Common World}

Latour's model for political ecology provides a suitable lens through which to analyze current debates on GMOs and their regulation. The model's central premise is that all such deliberative processes are part of the political and value-laden project of constructing a good common world: one in which techno-scientific developments do not return at later stages and in surprising ways to disrupt the collective sense of comfort and safety. It reworks the idea of ethics and redistributes responsibility for it beyond ethicists: to scientists and their recognition of perplexity, politicians who must ensure proper consultation among new actors and reliable witnesses, and administrators/bureaucrats who musts perform truthful and accurate recordings of deliberations performed and decisions made. Vice versa, the idea of knowledge production is reworked to include questions of consultation and ethics. Latour's model outlines new and broader forms of co-construction of knowledge and value negotiation that may help long-standing efforts to democratize predominantly science-based consultations on gene technology. This is especially important in debates where government-appointed actors like NBAB employ discursive framings to de-politicize technology in contrast to NGOs' aim to politicize it [30].

Where current forms of knowledge production reach their limits is where we must acknowledge perplexity. By allowing us to distinguish between complexities-that which, through careful and holistic research approaches, may be resolved, and perplexities-that which lies beyond the scope of current knowledge-production systems-Latour's model for political ecology facilitates a concretization of public concern for perplexities (or at least provides a category in which to place and account for such concerns). Integrating these in the consultation processes seems precisely to be the aim of agricultural and environmental organizations who value current production systems (traditional as well as ecological) and ecosystem services whose full magnitude of complexity/interaction tend to remain undetected until contaminated or broken [54]. Their call to maintain the democratic processes involved in the current regulation on GMO applications can be read as a call to allow openness to perplexity to remain, to allow processes of consultation to take as much time and include as many propositions and voices as possible. Accordingly, it is important that these voices not be silenced-particularly by governmental bodies officially assigned the role of ensuring proper consultations on gene technology. 


\section{Conclusions}

NBAB claims that gene technology will become an important and enabling technology within the emerging bioeconomy. In order to achieve this goal without significantly upsetting existing value systems, there is a profound need to reconsider the kind of knowledge production needed to engender proper and equitable processes of deliberation. We believe such knowledge production must not only be open about scientific and environmental perplexities involved in the development and use of new gene technologies, but also involve a broader range of actors from beyond the (molecular) sciences. Only through more inclusive deliberations that transcend ingrained fact-value/science-ethics distinctions and encompass nonhuman biological and/or ecological parts of the nature-culture collective can the new gene technologies fulfil the visions of sustainability that their proponents present.

Our case study demonstrates how poststructuralist discourse analysis inspired by Latour's model for political economy can be useful in gauging the openness of processes of consultation and seeking better and broader problem formulations in matters concerning the regulation and use of new gene technologies. Although focused on one specific and time-limited instance of public debate in Norway, a country known for its unique inclusion of non-safety considerations in GMO regulation, our study reveals a general need to consider the processes involved in public debates on gene technology in their entirety. Only thus will it be possible to detect the manner and extent to which discursive framings, selective emphasis on desired lines of argumentation, and partial reporting hinder fair and proper consultation and render engagement futile for certain actors.

Author Contributions: Conceptualization, S.K.; methodology, S.K.; formal analysis, S.K.; resources, S.K., T.A., S.H. and A.I.M.; writing - original draft preparation, S.K., T.A., S.H. and A.I.M.; writingreview and editing, S.K., T.A., S.H. and A.I.M.; visualization, S.K., T.A., S.H. and A.I.M. All authors have read and agreed to the published version of the manuscript.

Funding: This research was funded by The Research Council of Norway, grant number 283387.

Institutional Review Board Statement: Not applicable.

Informed Consent Statement: Not applicable.

Data Availability Statement: Data is contained within the article. See Table A1 Source data for discourse analysis.

Acknowledgments: We wish to thank Katrine Jaklin, GenØk Centre for Biosafety, for excellent administrative support and help with figure design, and our reviewers for valuable comments to our manuscript.

Conflicts of Interest: The following authors, S. Kjeldaas, T. Antonsen, and S. Hartley, declare no conflict of interest. A.I. Myhr contributed to the submission by the GenØk-Centre of Biosafety to the NBAB hearing. Myhr was appointed as a member of NBAB from April 2019; however, this appointment was after the work with reports D1 and D3. She was therefore not involved in the work with the proposal for relaxation.

\section{Appendix A}

Table A1. Source data for discourse analysis.

\begin{tabular}{llll}
\hline $\begin{array}{l}\text { Data } \\
\text { Category }\end{array}$ & Kind of Document & Document: & Document Length (in p) \\
\hline D1 & Hearing invitation & $\begin{array}{l}\text { Norwegian Biotechnology Advisory Board: } \\
\text { The Gene Technology Act-Invitation to Public Debate [22] } \\
\text { (Genteknologiloven-Invitasjon til offentlig debatt [24]) }\end{array}$ & $\begin{array}{l}52 \\
(52)\end{array}$ \\
\hline D2 & Hearing responses & $\begin{array}{l}\text { Norwegian Biotechnology Advisory Board: } \\
\text { Mottatte innspill (Replies received) [42] }\end{array}$ & \\
\hline
\end{tabular}


Table A1. Cont.

\begin{tabular}{|c|c|c|c|}
\hline $\begin{array}{l}\text { Data } \\
\text { Category }\end{array}$ & Kind of Document & Document: & Document Length (in p) \\
\hline & \multirow{11}{*}{$\begin{array}{l}\text { Umbrella } \\
\text { organizations (10) }\end{array}$} & Sjømat Norge (Seafood Norway) & 4 \\
\hline & & NHO Mat og Drikke (FoodDrinkNorway) & 4 \\
\hline & & Norsk Industri (The Federation of Norwegian Industry CNE) & 1 \\
\hline & & Legemiddelindustrien (The Medical Industry) & 3 \\
\hline & & Statens Legemiddelverk (The Norwegian Medicines Agency) & 4 \\
\hline & & Tekna (The Norwegian Society of Graduate Technical and & 5 \\
\hline & & $\begin{array}{l}\text { Scientific Professionals) } \\
\text { Norsk Gartnerforbund (Norwegian Growers' Association) }\end{array}$ & $\begin{array}{l}5 \\
2\end{array}$ \\
\hline & & Heidner Biocluster & 2 \\
\hline & & Norsk Landbrukssamvirke (Norwegian & 6 \\
\hline & & Agricultural Cooperation) & 6 \\
\hline & & $\begin{array}{l}\text { Nettverk for GMO-fri Mat og Fôr (Network for GMO-free } \\
\text { foods and animal feed) }\end{array}$ & 6 \\
\hline & \multirow{8}{*}{ Organizations (7) } & Norges Bondelag (Norwegian Farmers' Association) & 2 \\
\hline & & $\begin{array}{l}\text { Norsk Bonde- og Småbrukarlag (Norwegian Farmers' and } \\
\text { Smallholders' Association) }\end{array}$ & 2 \\
\hline & & Økologisk Norge (Oikos-Organic Norway) & 3 \\
\hline & & Bondens marked Norge (Farmer's Market Norway) & 3 \\
\hline & & Norges Bygdekvinnelag (Norway's Rural & 3 \\
\hline & & Women's Association) & \\
\hline & & $\begin{array}{l}\text { Norges Naturvernforbund (Norwegian Society for the } \\
\text { Conservation of Nature) }\end{array}$ & 4 \\
\hline & & $\begin{array}{l}\text { Natur og Ungdom (Nature and Youth-Young Friends of the } \\
\text { Earth Norway) }\end{array}$ & 3 \\
\hline & \multirow{19}{*}{$\begin{array}{l}\text { Scientific } \\
\text { institutions and } \\
\text { environments (17) }\end{array}$} & Norsvin/Geno/Aqua Gen & 3 \\
\hline & & Graminor & 4 \\
\hline & & Uni Research & 2 \\
\hline & & Benchmark Genetics & 4 \\
\hline & & ACD Pharmaceuticals AS & 2 \\
\hline & & $\begin{array}{l}\text { Fakultet for Biovitenskap, NMBU (Faculty of Biosciences, } \\
\text { Norwegian University of Life Sciences) }\end{array}$ & 3 \\
\hline & & Institutt for Naturhistorie, NTNU (NTNU University & \\
\hline & & Museum's Department of Natural History, Norwegian & 3 \\
\hline & & University of Science and Technology) & \\
\hline & & Havforskningsintituttet (Institute of Marine Research) & 2 \\
\hline & & Genøk-Senter for biosikkerhet (GenØk-Center for Biosafety) & 13 \\
\hline & & Institutt for biovitenskap, UiB (Department of Biological & 4 \\
\hline & & $\begin{array}{l}\text { Sciences, University of Bergen) } \\
\text { Nofima }\end{array}$ & 2 \\
\hline & & $\mathrm{UiO}$ (University of Oslo) & 5 \\
\hline & & 13 researchers $\mathrm{NMBU} / \mathrm{NIBIO} / \mathrm{UiO}$ & 3 \\
\hline & & Dorothy Dankel & 1 \\
\hline & & Audun Nerland & 12 \\
\hline & & Camilla H. Jensen og Åsmund Kaupang & 7 \\
\hline & & Thomas Tichelkamp & 3 \\
\hline & \multirow{4}{*}{ Other institutions (4) } & Landbruksdirektoratet (Norwegian Agriculture Agency) & 1 \\
\hline & & Kirkerådet (Church of Norway) & 5 \\
\hline & & NENT (National Committee for Research Ethics in Science & 3 \\
\hline & & Ryggvold Melkeproduksjon (Ryggvold Milk Production) & 1 \\
\hline & \multirow{8}{*}{ Other individual responses (8) } & Liv Langberg & 4 \\
\hline & & Øyvind Nilsen & 1 \\
\hline & & Knut Morten Nyberg & 3 \\
\hline & & Sigmund Ramberg & 3 \\
\hline & & Pritam Bose & 2 \\
\hline & & Sigmund Berg & 3 \\
\hline & & Finn Kolberg & 6 \\
\hline & & Johannes Gaare & 5 \\
\hline
\end{tabular}


Table A1. Cont.

\begin{tabular}{llll}
\hline $\begin{array}{l}\text { Data } \\
\text { Category }\end{array}$ & Kind of Document & Document: & Document Length (in p) \\
\hline & & $\begin{array}{l}\text { Norwegian Biotechnology Advisory Board: } \\
\text { Proposal for relaxation of Norwegian regulations for deliberate } \\
\text { release of genetically } \\
\text { modified organisms (GMO), with applicability also for EU } \\
\text { legislation [25] } \\
\text { (Forslag til oppmykning av regelverket for utsetting av }\end{array}$ & 66 \\
& genmodifiserte organismer [43]) & (63) \\
\hline
\end{tabular}

\section{References}

1. Norwegian Gene Technology Act. Available online: https://www.regjeringen.no/en/dokumenter/gene-technology-act/id173 031/ (accessed on 31 March 2021).

2. European Union. Directive (EU) 2015/412 of the European Parliament and of the Council. Available online: https: / / op.europa. eu/en/publication-detail/-/publication/80d33e78-c94d-11e4-bbe1-01aa75ed71a1/language-ga (accessed on 31 March 2021).

3. Myhr, A.I.; Myskja, B. Non-safety Assessments of Genome-Edited Organisms: Should They be Included in Regulation? Sci. Eng. Ethics 2020, 26, 2601-2627.

4. European Union. Directive 2001/18/EC of the European Parliament and of the Council. Available online: https:/ / eur-lex.europa. eu/LexUriServ.do?uri=CONSLEG:2001L0018:20080321:EN:PDF (accessed on 2 July 2021).

5. Lovdata. Forskrift om Forbud mot Omsetning i Norge av Bestemte Genmodifiserte Produkter. Available online: https://lovdata. no/dokument/SF/forskrift/2000-12-15-1268 (accessed on 28 June 2021).

6. Norwegian Biotechnology Advisory Board. Sustainability, Benefit to the Community and Ethics in the Assessment of Genetically Modified Organisms: Implementation of the Concepts Set Out in Section 1 and 10 of the Norwegian Gene Technology Act. 2009. 2nd ed. Available online: https:/ / www.bioteknologiradet.no/filarkiv/2010/07/2009_11_18_diskusjonsnotat_baerekraft_engelsk. pdf (accessed on 14 May 2021).

7. Norwegian Biotechnology Advisory Board. Insektresistente Genmodifiserte Planter og Bærekraft. 2011. Available online: https:/ / www.bioteknologiradet.no/filarkiv/2011/06/rapport_baerekraft_110627_web.pdf (accessed on 14 May 2021).

8. Norwegian Biotechnology Advisory Board (NBAB). Herbicide-Resistant Genetically Modified Plants and Sustainability. 2014. Available online: https://www.bioteknologiradet.no/filarkiv/2014/09/Herbicide-resistant_genetically_modified_plants_and_ sustainability_NBAB.pdf (accessed on 14 May 2021).

9. Norwegian Biotechnology Advisory Board. Vurderinga frå Miljødirektoratet av den Genmodifiserte Maisen MON810Berekraft, Etikk og Samfunnsnytte. 2015. Available online: https://www.bioteknologiradet.no/filarkiv/2015/05/Om_Milj\T1 \odirektoratets_vurdering_av_MON810.pdf (accessed on 14 May 2021).

10. Forsberg, E.M.; Hofman, B.; Kaiser, M.; Myskja, B.; Strand, R.; Ursin, L. Veileder for Operasjonalisering av Vurderingskriteriet Etikk i Genteknologiloven. Cristin-Resultat-ID 1807181. 2019. Available online: https:/ / www.bioteknologiradet.no/filarkiv/20 10/07 / 2020-05-14-veileder-for-etikk-kriteriet-i-genteknologiloven.pdf (accessed on 6 July 2021).

11. Macnaghten, P.; Habets, M.G.J.L. Breaking the impasse: Towards a forward-looking governance framework for gene editing with plants. Plants People Planet 2020. [CrossRef]

12. Zetterberg, C.; Björnberg, K.E. Time for a New EU Regulatory Framework for GM Crops? J. Agric. Environ. Ethics 2017, 30, 325-347. [CrossRef]

13. Binimelis, R.; Myhr, A.I. Inclusion and Implementation of socio-economic considerations in GMO Regulations: Needs and Recommendations. Sustainability 2016, 8, 62. [CrossRef]

14. Norwegian Biotechnology Advisory Board. Norwegian Consumers' Attitudes towards Gene Editing in Norwegian Agriculture and Aquaqulture. 2020. Available online: https:/ / www.bioteknologiradet.no/filarkiv/2020/04/Report-consumer-attitudes-togene-editing-agri-and-aqua-FINAL.pdf (accessed on 29 June 2021).

15. Bugge, A.B. GMO Foods or not: Have there been Changes in Consumers' Views on Genetically Modified Foods from 2017 to 2020 ? SIFO-Report 3, 2020. Available online: https:/ / oda.oslomet.no/oda-xmlui/handle/20.500.12199/3001 (accessed on 29 June 2021).

16. Bugge, A.B.; Rosenberg, T.G. Fremtidens Matproduksjon. Forbrukernes Syn på Genmodifisert Mat: GMO-Mat Eller Ikke? SIFO-Rapport 2, 2017. Available online: https:/ / hdl.handle.net/20.500.12199/5345 (accessed on 29 June 2021).

17. Carson, S.G.; Myskja, B.K.; Myhr, A.I. Public engagement in biotechnology innovation-The need for research and the role of ethics. In Justice and Food Security in a Changing Climate; Schubel, H., Wallimann-Helmer, I., Eds.; Wageningen Academic Publishers: Wageningen, The Netherlands, 2021; pp. 301-306. [CrossRef]

18. Antonesn, T.; Bakkelund, T.B.; Dassler, T.; Kjeldaas, S. Hva Mener Nordmenn Egentlig om Genmodifisert mat? Aftenposten Viten 19 May 2020. Available online: https:/ / www.aftenposten.no/viten/i/awVVdE/hva-mener-nordmenn-egentlig-om-genmodifisertmat (accessed on 9 June 2021).

19. Antonsen, T.; Bakkelund, T.; Kjeldaas, S.; Wikmark, O.G. Problematisk Undersøkelse om Genredigering. Nationen Motkultur 29 April 2020. Available online: https:/ / www.nationen.no/motkultur/kronikk/problematisk-undersokelse-om-genredigering/ (accessed on 29 June 2021). 
20. Bartnes, L.P.; Hoff, K. Som du spør om Genredigering får du svar. Nationen Motkultur 27 April 2020. Available online: https: //www.nationen.no/motkultur/kronikk/som-du-spor-om-genredigering-far-du-svar/ (accessed on 29 June 2021).

21. Menozzi, D.; Kostov, K.; Sogari, G.; Arpaia, S.; Moyankova, D.; Mora, C. A stakeholder engagement approach for identifying future research directions in the evaluation of current and emerging applications of GMOs. BAE 2017, 6, 57-79. [CrossRef]

22. Norwegian Biotechnology Advisory Board. The Gene Technology Act-Invitation to Public Debate. 2018. Available online: https: / / www.bioteknologiradet.no/filarkiv / 2010/07/genteknologiloven-engelsk-hele-for-web-v-2.pdf (accessed on 31 March 2021).

23. Heide, B.R. Genmodifiserte organismer-Slik behandles søknadene. GENialt 2012, 1, 22-23.

24. Norwegian Biotechnology Advisory Board. Genteknologiloven-Invitasjon til Offentlig Debatt. 2017. Available online: https: //www.bioteknologiradet.no/filarkiv/2017/12/Genteknologiloven-uttalelse-invitasjon-til-offentlig-debatt-web.pdf (accessed on 1 December 2020).

25. Norwegian Biotechnology Advisory Board. Proposal for Relaxation of Norwegian Regulations for Deliberate Release of Genetically Modified Organisms (GMO), with Applicability also for EU Legislation. 2018. Available online: https://www. bioteknologiradet.no/filarkiv/2019/03/2019-04-16-Genteknologiloven-komplett-ENGELSK.pdf (accessed on 31 March 2020).

26. Bratlie, S.; Halvorsen, K.; Myskja, B.K.; Mellegård, H.; Bjorvatn, C.; Frost, P.; Heiene, G.; Hofmann, B.; Holst-Jensen, A.; Holst-Larsen, T.; et al. A novel governance framework for GMO. EMBO Rep. 2019, 20, e47812. [CrossRef] [PubMed]

27. Schmidt, S.M.; Belisle, M.; Frommer, W.B. The evolving landscape around genome editing in agriculture. EMBO Rep. 2020, 21, e50680. [CrossRef] [PubMed]

28. Latour, B. Politics of Nature: How to Bring the Sciences into Democracy; Trans by Catherine Porter; Harvard University Press: Cambridge, MA, USA, 2004.

29. Jasanoff, S.; Hurlburt, J.B.; Saha, K. CRISPR Democracy: Gene Editing and the Need for Inclusive Deliberation. Issues Sci. Technol. 2015, 32, 25-32.

30. Helliwell, R.; Hartley, S.; Pearce, W. NGO perspectives on the social and ethical dimensions of plant genome-editing. Agric. Hum. Values 2019, 36, 779-791. [CrossRef]

31. Hartley, S. Policy masquerading as science: And examination of non-state actor involvement in European risk assessment policy for genetically modified animals. J. Eur. Public Policy 2016, 23, 276-295. [CrossRef]

32. Jasanoff, S. Designs on Nature; Princeton University Press: Princeton, NJ, USA, 2005.

33. Wynne, B. Creating Public Alienation: Expert Cultures of Risk and Ethics on GMOs. Sci. Cult. 2001, 10, 445-481. [CrossRef] [PubMed]

34. Rowe, G.; Frewer, L.J. A typology of Public Engagement Mechanisms. Sci. Technol. Hum. Values 2005, 30, 251-290. [CrossRef]

35. Amilien, V.; Tocco, B.; Strandbakken, P. At the heart of controversies: Hybrid forums as an experimental multi-actor tool to enhance sustainable practices in localized agro-food systems. Br. Food J. 2019. [CrossRef]

36. European Group on Ethics in Science and New Technologies. Ethics of Genome Editing. 2021. Available online: https:/ / op.europa. eu/en/web/eu-law-and-publications/publication-detail/- / publication/6d9879f7-8c55-11eb-b85c-01aa75ed71a1 (accessed on 25 April 2021).

37. European Commission. Study on the Status of New Genomic Techniques under Union Law and in Light of the Court of Justice Ruling in Case C-528/16. 2021. Available online: https://ec.europa.eu/food/plants/genetically-modified-organisms/newtechniques-biotechnology /ec-study-new-genomic-techniques_en (accessed on 7 July 2021).

38. Fisher, K.; Ekener-Pedersen, E.; Rydhmer, L.; Björnberg, K.E. Social impacts of GM crops in agriculture: A systematic literature review. Sustainability 2015, 7, 8598-8620. [CrossRef]

39. Food and Agriculture Organization of the United Nations. SAFA Guidelines Version 3.0. 2014. Available online: http://www.fao. org/3/i3957e/i3957e.pdf (accessed on 20 May 2021).

40. European Commission. The European Green Deal. 2019. Available online: https://eur-lex.europa.eu/legal-content/EN/TXT/ ?uri=COM\%3A2019\%3A640\%3AFIN (accessed on 19 May 2021).

41. European Commission. Farm to Fork Strategy. 2020. Available online: https://ec.europa.eu/food/system/files/2020-05/f2f_ action-plan_2020_strategy-info_en.pdf (accessed on 7 July 2021).

42. Norwegian Biotechnology Advisory Board. Mottatte Innspill. 2018. Available online: https://www.bioteknologiradet.no/2018/1 2/genteknologiloven/ (accessed on 1 December 2020).

43. Norwegian Biotechnology Advisory Board. Forslag til Oppmykning av Regelverket for Utsetting av Genmodifiserte Organismer. 2018. Available online: https:/ / www.bioteknologiradet.no/filarkiv/2018/12/2018-12-03-Komplett-genteknologilovenBioteknologirådet-til-web.pdf (accessed on 1 December 2020).

44. Bacchi, C.L. Analysing Policy: What's the Problem Represented to Be? Pearson: Frenchs Forest, Australia, 2009.

45. Bacchi, C.; Goodwin, S. Poststructural Policy Analysis; Palgrave: New York, NY, USA, 2016.

46. European Commission (Scientific Advice Mechanism). New Techniques in Agricultural Biotechnology. 2017. Available online: https:/ / ec.europa.eu/info/publications/new-techniques-agricultural-biotechnology_en (accessed on 2 July 2021).

47. Siipi, H. Dimensions of naturalness. Ethics Environ. 2008, 13, 71-103. [CrossRef]

48. Latour, B. We Have Never Been Modern; Trans by Catherine Porter; Harvester: New York, NY, USA, 1993.

49. Myhr, A.I. A Precautionary Approach to Genetically Modified Organisms: Challenges and Implications for Policy and Science. J. Agric. Environ. Ethic 2010, 23, 501-525. [CrossRef] 
50. Nielsen, K.M.; Myhr, A.I. Understanding the uncertainties arising from technological interventions in complex biological systems: The case of GMOs. In Biosafety First; Traavik, T., Ching, L.L., Eds.; Tapir Academic Press: Trondheim, Norway, 2007 ; pp. 107-122.

51. Sandler, R.L. The Ethics of Species: An Introduction; Cambridge University Press: Cambridge, UK, 2012.

52. Court of Justice of the European Union. Judgement ECLI:EU:C:2018:538. 2018. Available online: https://curia.europa.eu/juris/ documents.jsf?num=C-528/16 (accessed on 14 May 2021).

53. Foucault, M. The Archaeology of Knowledge; Vintage: New York, NY, USA, 2010.

54. Swanson, H.; Tsing, A.; Bubandt, N.; Gan, E. Introduction: Bodies Tumbled into Bodies. In Arts of Living on a Damaged Planet; Tsing, A., Swanson, H., Gan, E., Bubandt, N., Eds.; University of Minnesota Press: Minneapolis, MN, USA, 2017 ; pp. M1-M12. 